\title{
Defence, oviposition and sex : semiochemical parsimony in two species of ladybird beetles (Coleoptera, Coccinellidae)? A short review.
}

\author{
JEAN-LOUIS HEMPTINNE ${ }^{1}$ and ANTHONY F.G. DIXON ${ }^{2}$ \\ ${ }^{1}$ Ecole $\mathrm{n}$ ationale de Formation agronomique, BP 87, F-31326 Castanet-Tolosan, France \\ ${ }^{2}$ School of Biological Sciences, University of East Anglia, Norwich NR4 7TJ, UK
}

Keywords. semiochemical parsimony, alkanes, oviposition deterring pheromone, mate recognition, defensive allomone, Coccinellidae, Adalia bipunctata, Coccinella septempunctata

\begin{abstract}
Certain alkanes or their mixture present on the surface of ladybird elytra is important in the recognition of potential mates. Similar chemicals are present in the tracks of larvae, which deter conspecific female ladybirds from laying eggs in aphid colonies already being attacked by larvae. Finally, the shell of ladybird eggs is covered with alkanes that deter other species of ladybirds from eating the eggs. In each case the alkanes are similar although they fulfil different functions. There are, therefore, indications that ladybirds exploit their natural product with parsimonious versatility.
\end{abstract}

\section{INTRODUCTION}

Ladybirds are often seen as competitors of ants in the exploitation of aphids or as prey for insectivorous birds. Most aphidophagous ladybirds are brightly coloured, distasteful and emit droplets of haemolymph from their leg joints when molested. These droplets are bitter tasting, often has a strong smell, are toxic to birds (Marples et al., 1989) and repels ants (Pasteels et al., 1973). It is therefore not surprising that a lot of attention has been paid to the chemical defences of these beetles. This line of research resulted in the discovery of defence allomones containing a single species-specific alkaloid (Pasteels et al., 1973; Ayr \& Browne, 1977; Jones \& Blum, 1983) or a speciesspecific blend of alkaloids (Lognay et al., 1996). As it is the case with many other aposematic insects, the smell is due, at least in part, to 2-isopropyl-3-methoxy-pyrazine (Al Abassi et al., 1998; Dixon, 2000). Until recently, these allomones were the only semiochemicals known from ladybirds beetles.

However, ants and birds are not the only enemies of ladybirds. An aphid population attracts several species of aphidophagous predators, although the frequency distributions of species is strongly positively skewed with one to three species being dominant (Hemptinne, 1989; see examples in Hodek \& Honěk, 1996). A ladybird larva is therefore highly likely to meet another ladybird of its own species or another aphid predator. Intraguild encounters probably constitute a major risk for ladybirds (Cottrell \& Yeargan, 1998; Lucas, 1998; Lucas et al., 1998; Obrycki et al., 1998; Schellhorn \& Andow, 1999; 2000). Eggs and first instar larvae are particularly vulnerable to cannibalism (Agarwala \& Dixon, 1992; Majerus, 1994; Lucas et al., 1998; Schellhorn \& Andow, 1999) and egg cannibalism increases with the density of larvae, which is positively linked to the abundance of aphids (Mills, 1982). Cannibalism and intraguild predation always appear to be asymmetrical with the larger individuals eating the smallest or immobile instars (Agarwala \& Dixon, 1992; Rosenheim et al., 1995; Lucas et al., 1998).

The choice of oviposition site is therefore a critical determinant of female fitness. An abundance of prey is not the sole criterion because it is often associated with a high level of egg cannibalism. In view of the risks faced by ladybird larvae, the choice should depend on cues that indicate the future availability of food for larvae and the risk of intraguild predation. Before laying an egg, aphidophagous hoverflies hover in front of an aphid colony. If winged aphids, are absent what is a sign that the colony is young and will last long enough to sustain larval development, they deposit an egg (Kan, 1988a,b). Apart from the cases of large Coccinellids there is no clear indication that vision intervenes in the foraging behaviour of ladybird females (Hodek \& Honěk, 1996), therefore, these must rely on other sources of information.

Ladybird males probably have the same sensory limitations as females. When searching aphid infested plants they possibly do not use their eyes to recognise potential mates. How then do they find a female?

Our studies on mate recognition, cannibalism, intraguild predation and selection of oviposition sites by Adalia bipunctata (L.) and Coccinella septempunctata L. have revealed that several semiochemicals are involved. In this paper the substances that these beetles probably use as cues in defence, oviposition and sex are analysed and compared. It also addresses the question of whether ladybirds exploit their natural products with parsimonious versatility (Blum, 1996).

\section{RECOGNITION OF POTENTIAL MATES}

The pattern of activity of male $A$. bipunctata is not determined by the abundance of prey contrary to females (Hemptinne et al., 1996). Plants infested with aphids are just places where males seek for potential mates. On meeting a mature female, males of $A$. bipunctata react very quickly. In an interval of about $10 \mathrm{~s}$, they climb onto 
the back of the female; extrude their genitalia, align themselves and attempt copulation. The proportion of males that palpate and mount males is not significantly different from that observed to behave this way when they encounter a female. However, the proportion that subsequently extrude their penis and mate is lower in homosexual than heterosexual pairs. The behaviour of males is similar when they encounter a ladybird sized pellet of Blu Tak ${ }^{\circledR}$ bearing a fresh pair of female or male elytra (Fig. 1) (Hemptinne et al., 1998).

A Blu Tak® dummy with female elytra washed in chloroform for $24 \mathrm{~h}$ do not elicit mating. A similar dummy bearing washed elytra that have been painted with the chloroform extract of two elytra again become attractive to males as unwashed elytra (Fig. 1). Thus, the chloroform removes the chemicals that make elytra attractive to males.

A pair of elytra is covered by approximately $12 \mu \mathrm{g}$ of a mixture of 44 alkanes of which 14 major compounds make $1 \%$ or more of the chloroform extract. The shorter molecules have 21 atoms of carbon and the longest 33 (Table 1).

The alkanes are probably species specific because the response of two-spot males is weaker in the case of dummies with fresh elytra of $A$. decempunctata (Hemptinne et al., 1998).

TABLE 1 . The compounds that make up $1 \%$ or more of the chloroform extract of a pair of elytra of Adalia bipunctata.

\begin{tabular}{cc}
\hline Compounds & $\%$ \\
\hline $\mathrm{nC}_{21}$ & 6.9 \\
$\mathrm{Me}_{22}$ & 1.6 \\
$\mathrm{nC}_{23}$ & 7.6 \\
$\mathrm{MeC}_{23}$ & 42.3 \\
$\mathrm{diMeC}_{23}$ & 3.0 \\
$\mathrm{MeC}_{24}$ & 2.5 \\
$\mathrm{nC}_{25}$ & 3.9 \\
$\mathrm{MeC}_{25}$ & 2.9 \\
$\mathrm{nC}_{27}$ & 3.9 \\
$\mathrm{MeC}_{33}$ & 1.0 \\
$\mathrm{diMeC}_{33}$ & 1.7 \\
\hline
\end{tabular}

\section{SELECTION OF OVIPOSITION SITES}

The larvae of some species of ladybird beetles feed exclusively on aphids. Females of A. bipunctata tend to lay their eggs over a short period of time early in the development of a colony of aphids, the "egg window" (Hemptinne et al., 1992; Dixon, 1997). As a consequence their numerical reproductive response is only weakly, if correlated at all, with the abundance of prey. This reproductive strategy is adaptive as prey abundance in a habitat fluctuates dramatically over a 5 to 6 week period and only ladybirds born early in the development of a patch of prey are likely to mature before the aphids disappear.

In selecting suitable patches of prey ovipositing females do not respond to cues associated with the age structure of the aphid colony, as has been reported for hoverflies (Kan, 1988a,b), or the phenology of the host-plant (Hemptinne et al., 2000a). They refrain from ovipositing in patches where there are few aphids (Dixon, 1959) and

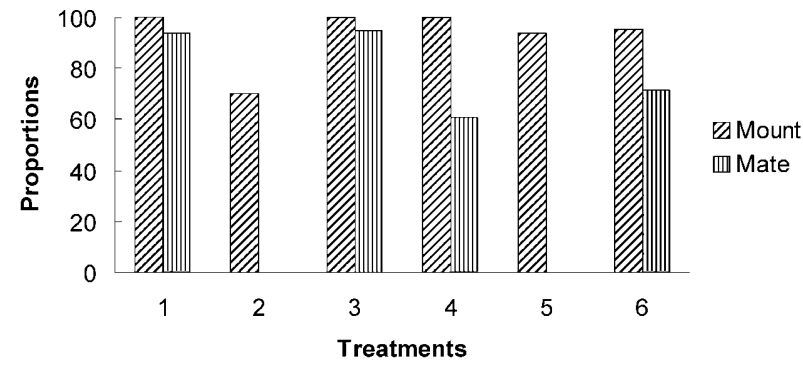

Fig. 1. The proportions of males of Adalia bipunctata that mounted and mated a conspecific female (1) or male (2), a dummy bearing two conspecific elytra of a female (3) or a male (4), a dummy bearing the elytra of a conspecific female that have been washed in chloroform (5) or a dummy bearing the elytra of a conspecific female that have been washed in chloroform and on which the chloroform extract has been re-applied (6)

conspecific larvae are present (Hemptinne et al., 1992, 1993). Females do not need to encounter larvae but respond to an oviposition deterring pheromone present in the tracks of the larvae. This pheromone is soluble in chloroform and its deterrent effect is concentration dependent (Doumbia et al., 1998). C. septempunctata and several species of lacewings behave similarly (Neuroptera: Chrysopidae). Larvae chemically mark the substrate with a substance secreted from the tip of their abdomen. This substance is soluble in chloroform and deters females from ovipositing (Rů $\square$ ička, 1994, 1996, 1997).

To identify the pheromone, late third instar larvae of $A$. bipunctata were isolated in $5 \mathrm{~cm}$ diameter Petri dishes and after moulting to the fourth instar, were fed an excess of pea aphids for $24 \mathrm{~h}$. Each larva was then carefully placed in a glass tube where it remained without food for $24 \mathrm{~h}$. Larvae treated in this way did not produce faeces or contaminate the tube by reflex bleeding as it is the case when larvae interact with one another. As the larvae were hungry they spent most of the time walking. After $24 \mathrm{~h}$

TABLE 2. The compounds that make up $1 \%$ or more of the chloroform extract of the tracks of larvae of Adalia bipunctata.

\begin{tabular}{cc}
\hline Compounds & $\%$ \\
\hline $\mathrm{nC}_{21}$ & 3.2 \\
$\mathrm{nC}_{23}$ & 3.3 \\
$\mathrm{MeC}_{23}$ & 3.9 \\
$\mathrm{MeC}_{24}$ & 4.3 \\
$\mathrm{nC}_{25}$ & 15.1 \\
$\mathrm{MeC}_{25}$ & 7.7 \\
$\mathrm{MeC}_{26}$ & 1.4 \\
$\mathrm{nC}_{27}$ & 1.8 \\
$\mathrm{MeC}_{27}$ & 1.6 \\
$\mathrm{nC}_{29}$ & 1.7 \\
$\mathrm{MeC}_{29}$ & 4.7 \\
$\operatorname{diMeC}_{29}$ & 3.9 \\
$\mathrm{nC}_{31}$ & 3.7 \\
$\mathrm{MeC}_{31}$ & 6.9 \\
$\mathrm{MeC}_{33}$ & 4.8 \\
$\operatorname{diMeC}_{33}$ & 2.9 \\
$\mathrm{Squalene}$ & 4.4 \\
\hline
\end{tabular}


the larva was removed and the tube washed with chloroform. The chloroform extracts of 25 larvae were pooled, treated as a replicate and analysed by GC-MS (Gas chromatography-Mass Spectrometry) and GLC (Gas Liquid chromatography) (Hemptinne et al., 1998).

In the above experimental conditions, a larval track consisted of 8 to $10 \mu \mathrm{g}$ of material deposited in the glass tube. At least forty different components, mostly alkanes, were identified in the tracks. Seventeen molecules make up $1 \%$ or more of this extract (Table 2). The principal constituent of the tracks of larvae is n-pentacosane $\left(\mathrm{nC}_{25}\right)$ accounting for $15.1 \%$ (Hemptinne et al., in press).

\section{DEFENCE OF EGGS FROM CANNIBALISM AND INTRAGUILD PREDATION}

Both in terms of intraguild predation and cannibalism, the eating of eggs by ladybirds would appear to be advantageous because it supplies a source of food and removes potential competitors. However, the larvae of $A$. bipunctata and $C$. septempunctata, which may co-occur in the field (Smee, 1922; Banks, 1955, 1956; Smith, 1966; Radwan \& Lövei, 1982, 1983; Honěk, 1985; Hemptinne \& Naisse, 1988; Hemptinne, 1989; Majerus, 1994; Barczak et al., 1996; Trouvé et al., 1996), are reluctant to eat conspecific eggs painted with water extracts of whole eggs of the other species. Larvae of $C$. septempunctata are more likely to die after eating a few eggs of $A$. bipunctata than vice versa (Agarwala \& Dixon, 1992). The water extract of crushed whole eggs is however likely to contain the species specific alkaloids that are known to be present in ladybird eggs (Pasteels et al., 1973). Some of these alkaloids are known to be toxic to vertebrates (Frazer \& Rothschild, 1960; Marples et al., 1989) and therefore it does not seem unreasonable to assume they are responsible for the toxicity of ladybird eggs.

Although the eggs of ladybirds may be chemically defended, such defence would be of little value if the eggs are killed before their toxicity becomes apparent.

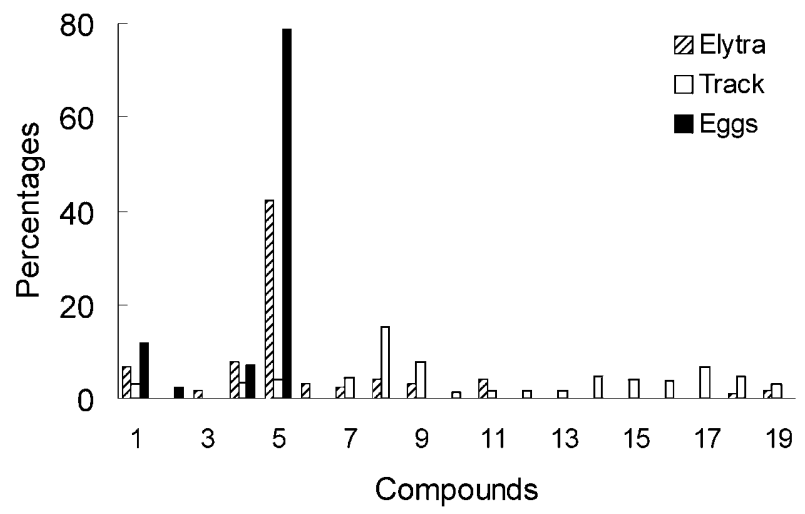

Fig. 2. Comparison of the composition of the chloroform extract of a pair of elytra and the tracks of larvae, and the hexane extract of the surface of eggs of Adalia bipunctata.

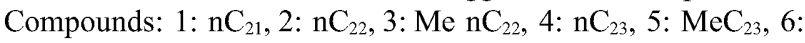
di $\mathrm{MeC}_{23}, 7: \mathrm{MeC}_{24}, 8: \mathrm{nC}_{25}, 9: \mathrm{MeC}_{25}, 10: \mathrm{MeC}_{26}, 11: \mathrm{nC}_{27}, 12$ : $\mathrm{MeC}_{27}, 13: \mathrm{nC}_{29}, 14: \mathrm{MeC}_{29}, 15: \mathrm{diMeC}_{29}, 16: \mathrm{nC}_{31}, 17: \mathrm{MeC}_{31}$, 18: $\mathrm{MeC}_{33}, 19: \mathrm{diMeC}_{33}$
Therefore, it would be advantageous for both predator and egg if the toxicity of the latter could be flagged in some way. This idea was tested by transferring a two day

TABLE 3. The number of fourth instar larvae of Adalia bipunctata and Coccinella septempunctata that ate eggs, and the number of eggs eaten, when offered either eggs of Adalia bipunctata that were unwashed, washed in $\mathrm{n}$-hexane or washed in n-hexane and painted with the hexane extract.

\begin{tabular}{|c|c|c|c|}
\hline & \multicolumn{3}{|c|}{ Eggs } \\
\hline & unwashed & washed & painted \\
\hline \multicolumn{4}{|c|}{ Larvae of $A$. bipunctata } \\
\hline$n_{t}$ & 21 & 21 & 21 \\
\hline $\mathrm{n}_{\mathrm{e}}$ & 7 & 18 & 7 \\
\hline$\chi^{2}$ test & \multicolumn{3}{|c|}{$15.37(\mathrm{P}<0.001)$} \\
\hline $\min$ & 0 & 0 & 0 \\
\hline $\max$ & 10 & 10 & 10 \\
\hline mean & 2.7 & 7.9 & 2.5 \\
\hline Kruskal & \multicolumn{3}{|c|}{$18.07(\mathrm{P}=0.000)$} \\
\hline \multicolumn{4}{|c|}{ Larvae of C. septempunctata } \\
\hline$n_{t}$ & 20 & 20 & 16 \\
\hline$n_{e}$ & 5 & 19 & 8 \\
\hline$\chi^{2}$ test & \multicolumn{3}{|c|}{$20.47(\mathrm{P}<0.001)$} \\
\hline $\min$ & 0 & 0 & 0 \\
\hline $\max$ & 10 & 32 & 10 \\
\hline mean & 1.8 & 11.8 & 1.9 \\
\hline Kruska & \multicolumn{3}{|c|}{$24.63(\mathrm{P}=0.000)$} \\
\hline
\end{tabular}

$\mathrm{n}_{\mathrm{t}}$ : total number of larvae; $\mathrm{n}_{\mathrm{e}}$ : number of larvae eating eggs

old fourth instar larvae of $A$. bipunctata, that had been starved for $3 \mathrm{~h}$, to a batch of a minimum 10 conspecific eggs. The number of eggs crushed or eaten was recorded. There were 21 replicates, which lasted for $15 \mathrm{~min}$ from the time of first encounter with the batch of eggs. Following the same procedure, a fourth instar larva of $A$. bipunctata was offered either a batch of conspecific eggs washed in n-hexane or a batch of conspecific eggs previously washed in n-hexane and then painted with an hexane extract obtained from a corresponding number of eggs. Eggs were immersed in $\mathrm{n}$-hexane for $2 \mathrm{~min}$. The washed and painted eggs were dried for $30 \mathrm{~min}$ before being presented to the larvae. Fourth instar larvae of $C$. septempunctata were also offered similarly treated eggs of $A$. bipunctata. The numbers of replicates varied from 20 to 16 depending on the treatment.

The fourth instar larvae of $A$. bipunctata ate numerically and proportionally significantly more washed than unwashed, or painted conspecific eggs. Fourth instar larvae of $C$. septempunctata were also reluctant to eat the eggs of $A$. bipunctata. Few of them consumed unwashed eggs or painted eggs. Significantly more washed eggs were eaten than unwashed or painted eggs (Table 3 ). It appears that the eggs of $A$. bipunctata are protected against both cannibalism and intraguild predation by $C$. septempunctata larvae by one or several n-hexane soluble substances on their surface (Hemptinne et al., 2000b). 
TABLE 4. The compounds of the hexane extract of the surface of the eggs of Adalia bipunctata.

\begin{tabular}{cc}
\hline Compounds & $\%$ \\
\hline $\mathrm{nC}_{21}$ & 11.9 \\
$\mathrm{nC}_{22}$ & 2.4 \\
$\mathrm{nC}_{23}$ & 7.1 \\
$\mathrm{MeC}_{23}$ & 78.6 \\
\hline
\end{tabular}

To determine the nature of these n-hexane soluble molecules, eggs of $A$. bipunctata were collected daily and 50 of them placed in a small conical flask. They were washed for $2 \mathrm{~min}$ in $500 \mu \mathrm{l}$ of $\mathrm{n}$-hexane. The dry residue of this extract was dissolved in $100 \mathrm{ml}$ of $\mathrm{n}$-hexane. The extracts from 22 groups of 50 eggs were pooled and analysed as explained in Hemptinne et al., 2000b. To measure the quantity of each of the compounds present in the extracts a solution of $12.05 \mathrm{mg}$ of $\mathrm{n}$-dodecane $/ 20 \mathrm{ml}$ of hexane was used as an internal standard (Hemptinne et al., 2000b).

The hexane extract of the surface of the eggs of $A$. bipunctata contains $87 \%$ of either linear hydrocarbons, heinecosane $\left(\mathrm{C}_{21}\right)$, docosane $\left(\mathrm{C}_{22}\right)$ and tricosane $\left(\mathrm{C}_{23}\right)$ or branched hydrocarbons , 7-methyl-tricosane (7-Me- $\left.\mathrm{C}_{23}\right)$ and 9-methyl-tricosane (9-Me- $\left.\mathrm{C}_{23}\right) .7-\mathrm{Me}-\mathrm{C}_{23}$ and 9-Me-C respectively represent 28.6 and $50 \%$ of the extract (Table 4). There was on average $4.20 \mu \mathrm{g}$ of hydrocarbon material on the surface of 50 eggs of $A$. bipunctata (Hemptinne et al., 2000b).

\section{SEMIOCHEMICAL PARSIMONY IN LADYBIRD BEETLES ?}

Following our studies, it appears that several vital functions of the ladybird A. bipunctata are served by semiochemicals. In addition to a defensive allomone known since the works of Tursch et al. (1971) and Pasteels et al. (1973) and that protects all stages of development from predation, three substances containing several alkanes intervene in the recognition of potential mates, in the assessment of the quality of aphid colonies and in the protection of eggs against cannibalism and intraguild predation. The exact chemical nature of the molecules releasing these behaviours is still unknown and some volatile semiochemicals may have been lost in the isolation procedure. However, the fact that ladybirds synthesise long chain hydrocarbons is interesting for two reasons. Firstly, the molecules of the larval track will spread easily on the hydrophobic cuticle of plant (Weier et al., 1974) and so leave a large signal. Secondly, saturated hydrocarbons are not quickly oxidised and are therefore stable, so are the signals delivered by larval tracks, egg shells or elytra. Our results and those of Liepert \& Dettner (1996) indicate that alkanes probably play a key role in the ecology of insects forming food chains on plants. Therefore, it is reasonable to focus on the alkanes present in the substances obtained from larval tracks, ladybird elytra and chorion in order to find the biologically active compounds intervening in the recognition of mates, in the assessment of the quality of aphid colonies and in the protection of eggs.

Blum $(1985,1996)$ insists that there are probably strong adaptation pressure for Arthropods to use the same semiochemicals for different purposes. The three substances obtained from $A$. bipunctata vary in the number and the relative importance of their alkanes. However, figure 2 shows that the extracts of egg surface, larval tracks and elytra have in common $\mathrm{nC}_{21}, \mathrm{nC}_{23}$ and different $\mathrm{MeC}_{23}, 7-\mathrm{MeC}_{23}$ and $9-\mathrm{MeC}_{23}$ being the most important. This chemical overlap suggests that ladybirds are parsimonious in their semiochemichals and that some ladybird alkanes deliver an information that is context dependent

ACKNOWLEDGEMENTS. This paper has been written while the authors benefited from a Joint Project Grant awarded by The Royal Society. The authors thank the Organising Committee of the 7th Aphidophaga Meeting of the I.O.B.C. for their invitation to present this lecture.

\section{REFERENCES}

Agarwala B.K. \& Dixon A.F.G. 1992: Laboratory study of cannibalism and interspecific predation in ladybirds. Ecol. Entomology 17: 303-309.

Al Abassi S., Birkett M.A., Pettersson J., Pickett J.A. \& WooDCoCK C.M. 1998: Ladybird beetle odour identified and found to be responsible for attraction between adults. Cell. Mol. Life Sci. 54: 876-879.

AYR W.A. \& BRownE L.M. 1977: The ladybug alkaloids including synthesis and biosynthesis. Heterocycles 7: 685-707.

BANKs C.J. 1955: An ecological study of Coccinellidae (Col.) associated with Aphis fabae Scop. on Vicia faba. Bull. Entomol. Res. 46: 561-587.

BANKs C.J. 1956: Observations on the behaviour and mortality in Coccinellidae before dispersal from the egg shells. Proc. R. Entomol. Soc. Lond. 31: 56-60.

Barczak T., Kaczorowsiki G. \& Burmistrzak M. 1996: Coccinellid beetles (Coccinellidae, Col.) associated with populations of Aphis fabae Scop. - complex (Aphididae, Hom.) on spindle bush. Preliminary results. In Narkiewicz-Jodko J., Cichocka E., Nawrocka B. \& Goszcynski W. (eds): Aphids and Other Homopterous Insects, (vol. 5). Polish Academy of Sciences Vth Division - Agricultural and forest Sciences, Skierniewice, pp. 15-22.

Buum M.S. 1985: Exocrine systems. In Blum M.S. (ed.): Fundamentals of Insect Physiology. John Wiley \& Sons, pp. 535-579.

BLuM M.S. 1996: Semiochemical parsimony in the Arthropoda. Annu. Rev. Entomol. 41: 353-374.

Cottrell T.E. \& Yeargan K.V. 1998: Intraguild predation between an introduced Lady Beetle, Harmonia axyridis (Coleoptera: Coccinellidae), and a native Lady Beetle, Coleomegilla maculata (Coleoptera: Coccinellidae). J. Kans. Entomol. Soc. 71: 159-163.

Dixon A.F.G. 1959: An experimental study of the searching behaviour of the predatory coccinellid beetle Adalia decempunctata (L.). J. Anim. Ecol. 28: 259-281.

Dixon A.F.G. 1997: Patch quality and fitness in predatory ladybirds. In Dettner et al. (eds): Vertical Food Web Interactions. Ecol. Studies 130: 205-223.

Dixon A.F.G. 2000: Insect Predator - Prey Dynamics. Ladybird Beetles \& Biological Control. Cambridge University Press, Cambridge, UK, $257 \mathrm{pp}$.

Doumbia M., Hemptinne J.-L. \& Dixon A.F.G. 1998: Assessment of patch quality by ladybirds: role of larval tracks. Oecologia 113: 197-202.

Frazer J.F.D. \& Rothschild M. 1960: Defence Mechanisms in Warmingly Coloured Moths and Other Insects. Proceedings 
11th International Congress of Entomology, Wien, Verhandlungen B 3, pp. 249-256.

Hemptinne J.-L. 1989: Ecophysiologie d'Adalia bipunctata (L.) (Coleoptera, Coccinellidae). PhD Thesis, Université Libre de Bruxelles, Belgium, $156 \mathrm{pp}$.

Hemptinne J.-L. \& NAisse J. 1988: Life cycle strategy of Adalia bipunctata (L.) (Col., Coccinellidae) in a temperate country. In Niemczyk E. \& Dixon A.F.G. (eds): Ecology and Effectiveness of Aphidophaga, SPB Academic Publishing, The Hague, pp 71-77.

Hemptinne J.-L., Dixon A.F.G. \& Goffin J. 1992: Attack strategy of ladybird beetles (Coccinellidae): factors shaping their numerical response. Oecologia 90: 238-245.

Hemptinne J.-L., Dixon A.F.G., Doucet J.-L. \& Petersen J.E 1993: Optimal foraging by hoverflies (Diptera: Syrphidae) and ladybirds (Coleoptera: Coccinellidae): mechanisms. Eur. J. Entomol. 90: 451-455.

Hemptinne J.-L., Dixon A.F.G. \& Lognay G. 1996: Searching behaviour and mate recognition by males of the two-spot ladybird beetle, Adalia bipunctata. Ecol. Entomol. 21: $165-170$.

Hemptinne J.-L., Lognay G. \& Dixon A.F.G. 1998: Mate recognition in the two-spot ladybird beetle, Adalia bipunctata: role of chemical and behavioural cues. J. Insect Physiol. 44: $1163-1171$

Hemptinne J.-L., Doumbia M. \& Dixon A.F.G. 2000a: Assessment of patch quality by ladybirds: role of aphids and plant phenology. J. Insect Behav. 13: 353-359.

Hemptinne J.-L., Lognay G., Gauthier C. \& Dixon A.F.G. 2000b: Role of surface chemical signals in egg cannibalism and intraguild predation in ladybirds (Coleoptera Coccinellidae). Chemoecology 10: in press.

Hemptinne J.-L., Lognay G., Doumbia M. \& Dixon A.F.G. 2001: Chemical nature and persistence of the oviposition deterring pheromone of the larvae of the two spot ladybird, Adalia bipunctata (Coleoptera: Coccinellidae). Chemoecology, in press.

HODEK I. \& HonĚK A. 1996: Ecology of Coccinellidae. Kluwer Academic Publishers, Dordrecht, $464 \mathrm{pp}$.

HoNĚK A. 1985: Habitat preferences of aphidophagous coccinellids (Coleoptera). Entomophaga 30: 253-264.

JONES T.H. \& BLUM M.S. 1983: Arthropod alkaloids: distribution, functions and chemistry. In Pelletier S.W. (ed): Alkaloids, Chemical and Biological Perspectives, Vol.1. John Wiley, New York, pp. 33-84.

Kan E. 1988a: Assessment of aphid colonies by hoverflies. I. Maple aphids and Episyrphus balteatus (de Geer) (Diptera: Syrphidae). J. Ethol. 6: 39-48.

KaN E. 1988b: Assessment of aphid colonies by hoverflies. II. Pea aphids and 3 syrphid species; Betasyrphus serarius (Wiedemann), Metasyrphus frequens Matsumara and Syrphus vitripennis (Meigen) (Diptera: Syrphidae). J. Ethol. 6: $135-142$

Liepert C. \& DetTner K. 1996: Role of hydrocarbons of aphid parasitoids in their relationship to aphid-attending ants. $J$. Chem. Ecol. 22: 695-707.

Lognay G., Hemptinne J.-L., Chan F., Gaspar C., Marlier M., Braekman J., Daloze D. \& Pasteels J. 1996: Adalinine, a new piperidine alkaloid from the ladybird beetles Adalia bipunctata and Adalia decempunctata. J. Nat. Prod. 59: $510-511$.

LuCAS E. 1998: How do ladybirds [Coleomegilla maculata lengi (Coleoptera: Coccinellidae)] feed on green lacewing eggs
[Chrysoperla rufilabris (Neuroptera: Chrysopidae)]? Can. Entomol. 130: 547-548.

LuCAS E., CODERRE D. \& BRODEUR J. 1998: Intraguild predation among aphid predators: characterization and influence of extraguild prey density. Ecology 79: 1084-1092.

MAJERUS M.E.N. 1994: Ladybirds. The New Naturalist, Harper Collins Publishers, London, $367 \mathrm{pp}$.

Marples N.M., BraKefield P. \& Cowie R.J. 1989: Differences between the 7-spot and 2-spot ladybird beetles (Coccinellidae) in their toxic effects on a bird predator. Ecol. Entomol. 14: 79-84.

Mills N.J. 1982: Voracity, cannibalism and coccinellid predation. Ann. Appl. Biol. 101: 144-148.

OBRYCKi J.J., GILes K.L. \& ORMORd A.M. 1998: Interactions between an introduced and indigenous coccinellid species at different prey densities. Oecologia 117: 279-285.

Pasteels J.M., Deroe C., Tursch B., Braekman J.C., Daloze D. \& Hootele C. 1973: Distribution et activités des alcalod'des défensifs des Coccinellidae. J. Insect Physiol. 19: 1771-1784.

RADWAN Z. \& LÖVEI G.L. 1982: Distribution and bionomics of ladybird beetles (Col., Coccinellidae) living on an apple orchard near Budapest, Hungary. Z. Angew. Entomol. 94: $169-175$.

RADWAN Z. \& LöveI G.L. 1983: Structure and seasonal dynamics of larval, pupal, and adult coccinellid (Col., Coccinellidae) assemblages in Hungary. Z. Angew. Entomol. 96: 396-408.

Rosenhem J.A., Kaya H.K., EhLer L.E., Marois J.J. \& JAFFeE B.A. 1995: Intraguild predation among biological control agents: theory and evidence. Biol. Control 5: 303-335.

RỦŽIČKA Z. 1994: Oviposition-deterring pheromone in Chrysopa oculata (Neuroptera: Chrysopidae). Eur. J. Entomol. 91: 361-370.

RŮžIČKA Z. 1996: Oviposition-deterring pheromone in Chrysopidae: intra- and interspecific effects. Eur. J. Entomol. 93: 161-166.

RŮŽIČKA Z. 1997: Recognition of oviposition-deterring allomones by aphidophagous predators (Neuroptera: Chrysopidae, Coleoptera: Coccinellidae). Eur. J. Entomol. 94: 439-434.

SCHELLHORN N.A. \& ANDOw D.A. 1999: Cannibalism and interspecific predation: role of oviposition behavior. Ecol. Appl. 9: 418-428.

SCHELLHORN N.A. \& ANDow D.A. 2000: Mortality of coccinellid beetle larvae and pupae when prey becomes scarce. Envir. Entomol. 26: 1092-1100.

SMEE C. 1922: British ladybird beetles. Their control of aphids. Fruit Grower 53: 675-676.

SмIтн B.D. 1966: Effects of parasites and predators on a natural population of the aphid Acyrthosiphon spartii (Koch) on broom (Sarothamnus scoparius L.). J. Anim. Ecol. 35: 255-267.

Trouvé C., Lédée S., Brun J. \& Ferran A. 1996: Lutte biologique contre les pucerons du houblon. Phytoma 486: 41-44.

Tursch B., Daloze D., Dupont M., Hootele C., Kaisin M., PasteEls J.M. \& ZimmermanN D. 1971: Coccinelline, the defensive alkaloid of the beetle Coccinella septempunctata. Chemia 25: $307 \mathrm{pp}$.

Weier T.E., Stocking C.R. \& Barbour M.G. 1974: Botany: an Introduction to Plant Biology. Wiley International Edition, New York, 693 pp.

Received January 6, 2000; accepted September 25, 2000 